\title{
ASSOCIATION BETWEEN ENERGY AND PROTEIN INTAKE, NUTRITIONAL STATUS, SERUM ALBUMIN AND QUALITY OF LIFE IN PATIENTS WITH CHRONIC RENAL FAILURE
}

\author{
Risda Sari ${ }^{1)}$, Sugiarto²), Ari Probandari3), Diffah Hanim ${ }^{1)}$ \\ 1)Masters Program in Nutrition, Sebelas Maret University \\ 2)Department of Internal Medicine, Dr. Moewardi Hospital, Surakarta \\ 3)Department of Public Health, Faculty of Medicine, Sebelas Maret University
}

\begin{abstract}
Background: Patients with chronic renal failure who have to undergo hemodialysis are at increased risk to have protein depletion and inflamation, which eventually may lead to decreased quality of life. These patients in turn experience uremia syndrome, which causes nausea, vomiting, and loss of appetite, and eventually low protein and energy intake. This study was aimed to determine the association between energy and protein intake, nutritional status, serum albumin and quality of life in patients with chronic renal failure. Subjects and Method: This was a cross-sectional study, conducted in Dr. Moewardi Hospital, Surakarta, from February to March, 2017. A sample of 142 patients with chronic renal failure who had to undergo hemodialysis were selected for this study. The dependent variable was quality of life. The independent variables were energy intake, protein intake, nutritional status, and serum albumin. Data on sample characteristics were collected by questionnaire and interview. Data on energy and protein intake were collected by $3 \times 24$ hour food recall. Nutritional status was measured by Subjective Global Assessment (SGA). Serum albumin and blood speciment were measured at the laboratory. Data on quality of life was measured by WHOQoL-BREF questionnaire. The data was analyzed by multiple logistic regression.
\end{abstract}

Results: Energy intake $(O R=2.01 ; p=0.394)$, protein intake $(O R=14.7 ; p=$ 0.99), nutritional status ( $O R=0.01 ; p=0.997)$, serum albumin $(O R=2.28 ; p=$ 0.156) were associated with increased quality of life in patient with chronic renal failure, but they were not statistically significant.

Conclusion: Energy intake, protein intake, nutritional status, serum albumin are associated with increased quality of life in patient with chronic renal failure, but they are not statistically significant.

Keywords: energy and protein intake, serum albumin, nutritional status, quality of life, patient, chronic renal failure

Correspondence: Risda Sari. Masters Program in Nutrition, Sebelas Maret University, Jl. Ir. Sutami 36 A, Surakarta 57126, Central Java.

Email: risdasari74@gmail.com. 